\title{
Molecular cloning and mRNA expression analysis of two GH secretagogue receptor transcripts in orange-spotted grouper (Epinephelus coioides)
}

\author{
Ting Chen, Zhiguo Tang, Aifen Yan, Wensheng Li and Haoran Lin \\ State Key Laboratory of Biocontrol, School of Life Sciences, Institute of Aquatic Economic Animals and Guangdong Provincial Key Laboratory for Aquatic \\ Economic Animals, Sun Yat-Sen University, Guangzhou 510275, People's Republic of China \\ (Correspondence should be addressed to W Li; Email: Isslws@mail.sysu.edu.cn)
}

\begin{abstract}
GH secretagogue receptor (GHSR) is the receptor of ghrelin, a circulating GH-releasing and appetite-inducing hormone. In this paper, two Ghsr cDNAs, gpGhsr1a and $g p G h s r 1 b$, were identified and characterized in a teleost, the orange-spotted grouper (Epinephelus coioides). The gpGHSR 1a is $1512 \mathrm{bp}$ in length with an open reading frame (ORF) that encodes a protein of 383 amino acids with seven transmembrane (TM) domains, while the $1703 \mathrm{bp}$ gpGHSR 1b contains an ORF encoding for 303 amino acids with five TM domains. Comparison between cDNA and gene sequences showed that the two transcripts are two alternative splicing forms of a single $g p G h s r$ gene. Tissue distribution and ontogeny of two $g p$ Ghsr mRNAs were examined by RT-PCR. The gpGHSR 1a is mainly expressed in brain and pituitary gland, when compared with a more
\end{abstract}

widespread expression of gpGHSR1b. During embryonic and larval development, the $g p G h s r 1 b$ mRNA appears before the gp Ghsr1a mRNA. Furthermore, quantitative real-time PCR performed on brain showed that both transcripts have the highest expression level in the pituitary gland. The expression level of gpGHSR1a was generally higher than that of gpGHSR1b. GHSR expressing cells were also detected widely in grouper brain by in situ hybridization, with a broader distribution than previous reports in mammals. Finally, an in vitro study showed that expression of both gpGHSR transcripts in pituitary and hypothalamus is downregulated by GH and ghrelin but not by des-acyl ghrelin, and this suggests that feedback regulation of GHSR also exists in teleostean fishes.

Journal of Endocrinology (2008) 199, 253-265

\section{Introduction}

The secretion of growth hormone $(\mathrm{GH})$ from the pituitary gland is mediated by a complex interplay of neuroendocrine factors (Peng \& Peter 1997, Muller et al. 1999, Wong et al. 2006). In addition, a group of artificial molecules known as GH secretagogues (GHSs) stimulates GH release (Bowers et al. 1980, 1984, Smith et al. 1997) via a 'novel' receptor, the GH secretagogue receptor (GHSR). The full-length GHSR, namely GHSR1a, is a G-protein-coupled receptor, which was first isolated from human and porcine pituitary cDNA libraries (Howard et al. 1996). An alternative splice variant of the GHSR, termed GHSR $1 \mathrm{~b}$, has also been found. It is a truncated receptor that has five transmembrane (TM) domains and is devoid of functional activity (Howard et al. 1996, McKee et al. 1997). The endogenous ligand of GHSR was subsequently identified from the rat stomach and named 'ghrelin' (Kojima et al. 1999). In mammals, ghrelin is a peptide of 28 amino acids (aa) with an essential n-octanoylation on the Ser3 residue (Bednarek et al. 2000, Yang et al. 2008) and implicated in many functions besides GH release (reviewed by van der Lely et al. 2004, Kojima \& Kangawa 2005).
The existence of ghrelin has now been demonstrated in nine teleostean species (reviewed by Unniappan \& Peter 2005, Kaiya et al. 2008): goldfish, Carassius auratus (Unniappan et al. 2002); Japanese eel, Anguilla japonica (Kaiya et al. 2003a); rainbow trout, Oncorhynchus mykiss (Kaiya et al. 2003b); two tilapia species, Oreochromis mossambicus (Kaiya et al. 2003c) and Oreochromis niloticus (Parhar et al. 2003); channel catfish, Ictalurus punctatus (Kaiya et al. 2005); black sea bream, Acanthopagrus schlegeli (Yeung et al. 2006); sea bass, Dicentrarchus labrax (Terova et al. 2008); and Atlantic halibut, Hippoglossus hippoglossus L. (Manning et al. 2008). Physiological roles of ghrelin in teleosts have also been widely studied, including effects on $\mathrm{GH}$ secretion (Riley et al. 2002, Kaiya et al. 2003a,b,c, Ran et al. 2004, Shepherd et al. 2007), appetite stimulation (Unniappan et al. 2002, 2004, Matsuda et al. 2006a, Jönsson et al. 2007, Miura et al. 2007, Shepherd et al. 2007), water intake (Kozaka \& Ando 2003), reproduction (Mustonen et al. 2002, Parhar et al. 2003), immunity (Yada et al. 2006), growth (Riley et al. 2005, Fox et al. 2007), intestinal motility (Olsson et al. 2008), and locomotor behavior (Matsuda et al. 2006a,b). 
However, the GHSR has only been identified from three species of teleosts: pufferfish, Spheroides nephelus (Palyha et al. 2000), black seabream (Chan \& Cheng 2004), and zebrafish, Danio rerio (Olsson et al. 2008), and a GHSR 1b transcript has only been found in black seabream (Chan \& Cheng 2004), not in pufferfish (Palyha et al. 2000) or zebrafish (Olsson et al. 2008). Teleostean GHSRs have high similarities with their mammalian counterparts, and the ligand activation domain of GHSR is evolutionarily conserved from pufferfish to man (Palyha et al. 2000). The mRNA distribution of GHSR in brain differs between black seabream (Chan \& Cheng 2004) and mammals (McKee et al. 1997, Gnanapavan et al. 2002). Furthermore, the signal transduction pathway (Chan et al. 2004) and the promoter activity (Yeung et al. 2004) of GHSR have also been studied in black seabream.

Compared with ghrelin, little work has been performed on teleostean GHSRs. Hence, some important basic aspects of the ghrelin/GHSR system, which are predicted to be specific for teleostean species, may have gone undetected so far. In this study, two transcripts of GHSR were obtained from the orange-spotted grouper, Epinephelus coioides, a marine fish widely cultured in Southern and Eastern China. We examined the mRNA expression of two transcripts in various tissues and during early development, and addressed the localization of Ghsr mRNA expression in the brain of this fish. Moreover, the effects of seabream GH, rat ghrelin, and rat des-acyl ghrelin on Ghsr mRNA expression were investigated in pituitary cells and hypothalamic fragments.

\section{Materials and Methods}

\section{Sampling of adult and juvenile grouper}

All adult and juvenile fish were obtained from Guangdong Daya-Bay Fishery Development Center $\left(22^{\circ} 36^{\prime} 2 \mathrm{~N}\right.$; $\left.114^{\circ} 32^{\prime} 45 \mathrm{E}\right)$. Two-year old female orange-spotted groupers, total length of 30-35 cm and body weight of 820-950 g, held at $22-28{ }^{\circ} \mathrm{C}$ seawater, were anesthetized in ice and killed by decapitation. Unfertilized and fertilized eggs were collected following natural spawning of brood stock kept in ferroconcrete tanks. Embryos were sampled from 1 to $20 \mathrm{~h}$ after fertilization including 16-cell stage, morula stage, blastula stage, gastrula stage, neurula stage, crystal stage, hatch prophase, and hatching. Larvae were reared in indoor ferroconcrete tanks and sampled from newly hatched to 5 days post-hatching (dph). Sampling of grouper embryos and larvae were described in detail previously (Li et al. 2005). The samples were snap-frozen in liquid nitrogen immediately until RNA extraction.

\section{cDNA and gene cloning of Ghsr in grouper}

Total RNA was extracted from adult grouper hypothalamus using Trizol reagent (Invitrogen) and quantified based on absorbance of the samples at $260 \mathrm{~nm}$. The RNA integrity was checked by agarose gel electrophoresis, and the purity was established by calculating the ratio of the absorbance readings at 260 and $280 \mathrm{~nm}$. First-strand cDNA was synthesized using Superscript III System (Invitrogen) with $4 \mu \mathrm{g}$ total RNA as template and oligo dT as primer. The experimental strategy of grouper Ghsr cDNA cloning is shown in Fig. 1, and all primer sequences used in this study are shown in Table. 1. Degenerate primers, $\mathrm{RpS1}, \mathrm{RpS} 2$, and RpA2, designed based on the alignment of known GHSR 1a sequences, were used to isolate a fragment of grouper GHSR 1a. The first-round PCR was performed using $1 \mu \mathrm{l}$ first-strand cDNA as template with RpS1 and RpA2. The semi-nested second-round PCR was performed using $1 \mu \mathrm{l}$ 100-fold diluted first-round PCR product as template with $\mathrm{RpS} 2$ and $\mathrm{RpA} 2$. In each case, the amplification condition consisted of an initial denaturation at $94{ }^{\circ} \mathrm{C}$ for $3 \mathrm{~min}, 35$ cycles of $94{ }^{\circ} \mathrm{C}$ for $15 \mathrm{~s}, 52^{\circ} \mathrm{C}$ for $15 \mathrm{~s}$ and $72{ }^{\circ} \mathrm{C}$ for $1 \mathrm{~min}$, and then a final extension at $72{ }^{\circ} \mathrm{C}$ for $5 \mathrm{~min}$.

The full-length cDNA was obtained using Rapid Amplification of cDNA Ends (RACE) methods. Five gene specific primers (GSP), R3-1, R3-2 R5-1, R5-2, and R5-3, were designed according to the obtained Ghsr1a cDNA fragment. For $3^{\prime}$-RACE, the first-strand cDNA was synthesized from $4 \mu \mathrm{g}$ total RNA using Superscript III System (Invitrogen) and Anchor Primer (AP, Gibco-BRL). The first-round PCR was performed using $1 \mu \mathrm{l}$ first-strand cDNA as template with R3-1 and Abridged Universal Amplification Primer (AUAP, GibcoBRL) under the following condition: an initial denaturation at $94{ }^{\circ} \mathrm{C}$ for $3 \mathrm{~min}, 35$ cycles of $94^{\circ} \mathrm{C}$ for $15 \mathrm{~s}, 56^{\circ} \mathrm{C}$ for $15 \mathrm{~s}$, and $72{ }^{\circ} \mathrm{C}$ for $1 \mathrm{~min} 30 \mathrm{~s}$, and then a final extension at $72{ }^{\circ} \mathrm{C}$ for $5 \mathrm{~min}$. The second-round PCR was performed using $1 \mu \mathrm{l}$ 100-fold diluted first-round PCR product as template with R3-2 and AUAP under the same cycling condition as the firstround PCR. For $5^{\prime}$-RACE, the first-strand cDNA was synthesized using Superscript III System (Invitrogen) with $4 \mu \mathrm{g}$ total RNA as template and R5-1 as primer. Subsequently, the synthesized cDNA was purified using E.Z.N.A Gel Extraction Kit (Omega, Norcross, GA, USA). After that, in a $50 \mu \mathrm{l}$ tailing reaction mixture, a homopolymeric tail was added to the $3^{\prime}$-end of the purified cDNA using Terminal deoxynucleotidyl Transferase (TaKaRa, Shiga, Japan) and dCTP (Invitrogen). The first-round PCR was performed using $2 \mu \mathrm{l}$ of the $\mathrm{dC}$-tailed reaction mixture as template with R5-2 and Abridged AP (Gibco-BRL) under the following condition: $94^{\circ} \mathrm{C}$ for $3 \mathrm{~min}, 35$ cycles of $94{ }^{\circ} \mathrm{C}$ for $15 \mathrm{~s}, 58{ }^{\circ} \mathrm{C}$ for $15 \mathrm{~s}$, and $72{ }^{\circ} \mathrm{C}$ for $1 \mathrm{~min}$, and then a final extension at $72{ }^{\circ} \mathrm{C}$ for $5 \mathrm{~min}$. The second-round PCR was performed using $1 \mu \mathrm{l} 100$-fold diluted first-round PCR product as template with R5-2 and AUAP under the same cycle profile

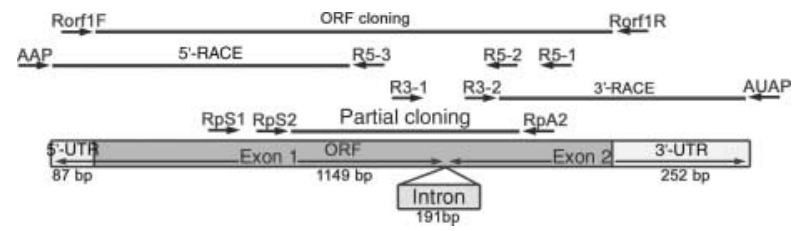

Figure 1 Experimental strategy used to obtain complete gpGhsr1a and gpGhsr $1 b$ cDNA. 
Table 1 Oligo-deoxynucleotide primers used in the experiments

\begin{tabular}{|c|c|c|}
\hline & Primer & Sequence \\
\hline \multicolumn{3}{|l|}{ Fragment } \\
\hline \multirow[t]{3}{*}{ gpGhsr1a cDNA partial cloning } & RpS1 & 5'-CCTSTGYATGCCSCTSGACCT-3' \\
\hline & RpS2 & 5'-CCACVRTSCTCAVCATCACMGCG-3' \\
\hline & $\mathrm{RpA} 2$ & $5^{\prime}$-TGTASAGRATRGGGTTGAT-3' \\
\hline \multirow[t]{2}{*}{ gpGhsR1a cDNA 3'-RACE } & R3-1 & $5^{\prime}$-CCAAAAGGCGGGTGCGCGCCC-3' \\
\hline & R3-2 & 5'-AAGCAACAGGCAGACCATC-3' \\
\hline \multirow[t]{3}{*}{ gpGhsr1a cDNA 5'-RACE } & R5-1 & 5'-ATTCCGTCCAGCCGTTTGAG-3' \\
\hline & R5-2 & 5'-CTTGATGGTCTGCCTGTTGCT-3' \\
\hline & $\mathrm{R} 5-3$ & $5^{\prime}$-CCACTGCGTAATGCGTCATC-3' \\
\hline \multirow{2}{*}{ gpGhsr1a and gpGhsr1b cDNA ORF cloning } & Rorf1F & 5'-CCGGGGTGCCTTCAGCAGT-3' \\
\hline & Rorf1R & 5'-AATGGCTTTGGGTGAGTGTTA-3' \\
\hline \multirow[t]{2}{*}{ gpGhsrla tissue distribution } & R1aTF & 5'-ATCAAGATGCTGGTGGTGGT-3' \\
\hline & R1aTR & 5'-TCCGTCCAGCCGTTTGAG-3' \\
\hline \multirow[t]{2}{*}{ gpGhsr $1 b$ tissue distribution } & R1bTF & 5'-CACCTCGCCCAGGCTGAAT-3' \\
\hline & R1bTR & $5^{\prime}$-AACGGCAACCAGCATAGAACG-3' \\
\hline \multirow[t]{2}{*}{ Reference gene $18 \mathrm{~S}$} & $18 \mathrm{SF}$ & 5'-ССТGAGAAACGGCTACСАСАТСС-3' \\
\hline & 18SR & 5'-AGCAACTTTAGTATACGCTATTGGAG-3' \\
\hline \multirow[t]{3}{*}{ Universal primer } & AUAP & 5'-GGCCACGCGTCGACTAGTAC-3' \\
\hline & AP & $5^{\prime}$-GGCCACGCGTCGACTAGTAC(T) $16^{-3^{\prime}}$ \\
\hline & AAP & 5'-GGCCACGCGTCGACTAGTACGGGIIGGGIIGGGIIG-3' \\
\hline
\end{tabular}

as the first-round PCR except that an annealing temperature of $56{ }^{\circ} \mathrm{C}$ was used instead.

To confirm that the composite sequence was indeed derived from a single mRNA transcript, a RT-PCR was performed using $1 \mu \mathrm{l}$ first-strand cDNA for partial cloning as template, with two GSPs, Rorf1F and Rorf1R, derived from the $5^{\prime}$ and $3^{\prime}$ ends of the composite sequence respectively. The amplification conditions consisted of an initial denaturation at $94^{\circ} \mathrm{C}$ for $3 \mathrm{~min}, 35$ cycles of $94^{\circ} \mathrm{C}$ for $15 \mathrm{~s}, 56^{\circ} \mathrm{C}$ for $15 \mathrm{~s}$, and $72{ }^{\circ} \mathrm{C}$ for $2 \mathrm{~min}$, and then a final extension at $72{ }^{\circ} \mathrm{C}$ for $5 \mathrm{~min}$.

For gene structure determination, genomic DNA was extracted from grouper liver using the classic Genome DNA Isolation kit (Bio Basic Inc., Markham, Ontario, Canada). A portion of Ghsr gene was amplified from $20 \mathrm{ng}$ genomic DNA by PCR with GSPs Rorf1F and Rorf1R. The PCR condition was: an initial denaturation at $94{ }^{\circ} \mathrm{C}$ for $3 \mathrm{~min}$, 35 cycles of $94{ }^{\circ} \mathrm{C}$ for $15 \mathrm{~s}, 56{ }^{\circ} \mathrm{C}$ for $15 \mathrm{~s}$, and $72{ }^{\circ} \mathrm{C}$ for $2 \mathrm{~min}$, and then a final extension at $72{ }^{\circ} \mathrm{C}$ for $5 \mathrm{~min}$.

PCR products were purified using E.Z.N.A Gel Extraction Kit (Omega) and subcloned into pGEM-T Easy vectors (Promega). The recombinant plasmids were sequenced from three independent clones using the ABI 3730 DNA sequencer (Applied Biosystems, Foster City, CA, USA). The homology was analyzed using MegAlign and the phylogenetic tree was constructed using PHYLIP and viewed using tree view. Reliability of the tree was evaluated by the bootstrap method with 1000 replications.

RT-PCR and qRT-PCR: tissue distribution and ontogeny of Ghsr $m R N A$

Tissue distribution and ontogeny of grouper Ghs mRNA were examined by semi-quantitative RT-PCR, and the expression levels of two GHSR transcripts in grouper brain were quantified by real-time PCR. Total RNA was extracted from 7 brain regions, 18 peripheral tissues, and 16 developmental stages of embryos and larvae. For larval samples, total RNA was extracted from the whole body. The total RNA was then quality verified and quantified as stated above for the cDNA cloning. Each RNA extract $(2 \mu \mathrm{g})$ was reversely transcribed into first-strand cDNA using ThermoScript RT-PCR System (Invitrogen) after it was treated by DNaseI (Invitrogen). The RNA sample was also tested for genomic DNA contamination by no enzyme reverse transcription control.

Firstly, for semi-quantitative RT-PCR, the GSPs R1aTF and R1aTR were designed to specifically amplify a GHSR1a fragment of $308 \mathrm{bp}$, and R1bTF and R1bTR were designed to specifically amplify a GHSR $1 \mathrm{~b}$ fragment of $188 \mathrm{bp}$. For tissue distribution, the semi-quantitative RT-PCR was validated using the RT product of hypothalamus as template by performing PCR in different cycles to determine the cycle numbers that generated half maximal PCR product and, for ontogeny, the RT product of $5 \mathrm{dph}$ was used as template instead. In the study of tissue distribution, PCRs were performed on 36 and 42 cycles for GHSR 1a and GHSR 1b respectively and, in the study of ontogeny, PCRs were performed on 42 cycles for both transcripts, under identical PCR conditions with a cycle profile of $94^{\circ} \mathrm{C}$ for $15 \mathrm{~s}, 57^{\circ} \mathrm{C}$ for $15 \mathrm{~s}$, and $72{ }^{\circ} \mathrm{C}$ for $30 \mathrm{~s}$. Ribosomal RNA $18 \mathrm{~S}$ was used as the internal control and amplified under the same condition as GHSR transcripts except that a tenfold diluted first-strand cDNA was used as template and the amplification cycle number was 18. RT-PCR products of both GHSR1a and GHSR1b were confirmed by Southern blot analysis. The procedure of Southern blot was as described by Li et al. 
(2005), and signal was captured using Genenome system (SynGene, Cambridge, UK).

Secondly, real-time PCR was additionally used to quantify the mRNA expression levels of two GHSR transcripts in grouper brain and pituitary. The brain was cut into seven dissected regions including olfactory bulbs, telencephalon, diencephalon, cerebellum, medulla, spinal cord, and hypothalamus. The real-time PCRs were performed using Platinum SYBR Green qPCR SuperMix-UDG (Invitrogen) in ABI PRISM 7900 Sequence Detection System (Applied Biosystems). Data obtained from three individuals of two GHSR transcripts were compared with data obtained from amplification of the reference gene, 18S. Primer pairs R1aTF/R1aTR, R1bTF/R1bTR, and 18SF/18SR were used to amplify the GHSR1a product of $308 \mathrm{bp}$, the GHSR 1b product of $188 \mathrm{bp}$, and the $18 \mathrm{~S}$ product of 250 bp respectively. The reaction $\operatorname{mix}(20 \mu \mathrm{l})$ contained $4 \mu \mathrm{l}$ RT product, $0 \cdot 4 \mu \mathrm{l}(10 \mu \mathrm{M})$ for each forward and reverse primers, $10 \mu \mathrm{l}$ Platinum SYBR Green qPCR SuperMixUDG, and $0 \cdot 4 \mu \mathrm{l}$ ROX reference Dye. All real-time PCRs were performed under the same conditions: $95^{\circ} \mathrm{C}$ for $10 \mathrm{~min}, 50$ cycles of $95^{\circ} \mathrm{C}$ for $30 \mathrm{~s}, 57^{\circ} \mathrm{C}$ for $30 \mathrm{~s}$, and $72^{\circ} \mathrm{C}$ for $1 \mathrm{~min}$. Fluorescent data for GHSR1a, GHSR 1b, and $18 \mathrm{~S}$ were collected at 87,82 , and $80^{\circ} \mathrm{C}$ respectively. Melt -curve analysis was performed over a range of $55-95^{\circ} \mathrm{C}$ to verify single product generation at the end of the assay. The standard curve quantification method was used to analyze the data. A standard curve for each gene was made from a tenfold dilution series of plasmid ranging from $10^{-4}$ to $10^{-10} \mathrm{ng}$ DNA. Data for all genes were converted to copy numbers, and data for two GHSR transcripts were then normalized with the geometric mean of the copy numbers determined for the reference gene, $18 \mathrm{~S}$.

\section{In situ hybridization (ISH) of GHSR expression cells in grouper brain}

Anti-sense and sense cRNA probes were synthesized from linearized GHSR plasmids using an in vitro transcription DIG-labeling Kit (Roche). One of the anti-sense probes was designed to detect all isoforms of GHSR and the other was designed to detect the GHSR1a isoform specifically.

Samples of brain were quickly removed and fixed overnight in $4 \%$ paraformaldehyde in phosphate buffer (PBS). Samples were dehydrated in an ethanol series, immersed in xylene, and embedded in paraffin. Sagittal and coronal sections $(8 \mu \mathrm{m})$ were cut and mounted onto 3-aminopropyltriethoxy-salanecoated slides.

Then the sections were deparaffinized with xylene, rehydrated through an ethanol series, and washed twice in PBS for $1 \mathrm{~min}$. The sections were then treated with $6 \mu \mathrm{g} / \mathrm{ml}$ proteinase $\mathrm{K}$ in proteinase $\mathrm{K}$ buffer $(0 \cdot 1 \mathrm{M}$ Tris- $\mathrm{HCl}$, and $50 \mathrm{mM}$ EDTA $(\mathrm{pH} 8 \cdot 0))$ at $37^{\circ} \mathrm{C}$ for $30 \mathrm{~min}$, washed once in PBS for $5 \mathrm{~min}$, and fixed in 4\% paraformaldehyde in PBS for $15 \mathrm{~min}$. The sections were rinsed twice in DEPC-treated water, incubated in $0.1 \mathrm{M}$ triethanolamine- $\mathrm{HCl}(\mathrm{pH} 8 \cdot 0)$ with $0 \cdot 25 \%$ acetic anhydride for $10 \mathrm{~min}$ and then washed in $\mathrm{PBS}$ for $5 \mathrm{~min}$. The sections were prehybridized in hybridization buffer ( $50 \%$ formamide, $5 \times$ SSC, $1 \times$ Denhardt's solution, $0 \cdot 1 \mathrm{mg} / \mathrm{ml}$ sonicated salmon sperm DNA, and $10 \%$ dextran sulfate) at $65^{\circ} \mathrm{C}$ for $1 \mathrm{~h}$. Subsequently, the probes diluted to $200 \mathrm{ng} / \mathrm{ml}$ were added into the hybridization buffer, and the sections were incubated at $48{ }^{\circ} \mathrm{C}$ for $16 \mathrm{~h}$ in a humid chamber. During hybridization, the sections were covered with PARAFILM (Alcan Packaging, Neenah, WI, USA), and sense probes were used as negative controls. After hybridization, the covers were removed by soaking the slides in $5 \times \mathrm{SSC}$. The sections were then washed twice in $2 \times \mathrm{SSC}$ at $67^{\circ} \mathrm{C}$ for $15 \mathrm{~min}$, once in $0.5 \times \mathrm{SSC}$ at $65^{\circ} \mathrm{C}$ for $15 \mathrm{~min}$, and then twice in $0 \cdot 2 \times \mathrm{SSC}$ at $65^{\circ} \mathrm{C}$ for $30 \mathrm{~min}$. The sections were incubated in buffer-1 (100 mM maleic acid (pH 7.5), $150 \mathrm{mM} \mathrm{NaCl}$ ) for $5 \mathrm{~min}$, immersed in $1.0 \%$ blocking reagent (Roche) prepared in buffer- 1 at $37^{\circ} \mathrm{C}$ for $1 \mathrm{~h}$, and finally incubated with alkaline phosphatase-conjugated antiDIG antibody (Roche) 1:2000 diluted in buffer-1 at $37^{\circ} \mathrm{C}$ for $30 \mathrm{~min}$. After that, the sections were washed twice in buffer-1 for $15 \mathrm{~min}$ and incubated in buffer-3 (100 mM Tris- $\mathrm{HCl}$ $(\mathrm{pH} \mathrm{9.5)}$ and $100 \mathrm{mM} \mathrm{NaCl})$ for $3 \mathrm{~min}$. The chromagen solution $(337 \mu \mathrm{g} / \mathrm{ml}$ 4-nitroblue tetrazolium chloride and $175 \mu \mathrm{g} / \mathrm{ml}$ 5-Bromo-4-chloro-3-indolyl phosphate dissolved in buffer-3) was added, and the sections were incubated until a visible signal was detected. The reaction was stopped by addition of a reaction stop solution $(10 \mathrm{mM}$ Tris- $\mathrm{HCl}$ $(\mathrm{pH} 7 \cdot 6)$ and $1 \mathrm{mM}$ EDTA $(\mathrm{pH} 8 \cdot 0)$ ). The sections were dehydrated with an ethanol series and vitrified with xylene, then mounted with neutral balsam. All sections were viewed and photographed with an Axiovert 40 CFL microscope (Zeiss, Thornwood, NY, USA).

\section{Regulation of Ghsr mRNA expression in pituitary and hypothalamus}

Grouper pituitary cells were prepared by a modified enzyme digestion method (Wong et al. 1998). The pituitary glands were washed with M199 medium containing antibiotics $(100 \mathrm{U} / \mathrm{ml}$ penicillin and $100 \mathrm{U} / \mathrm{ml}$ streptomycin) and digested with $1 \mathrm{mg} / \mathrm{ml}$ trypsin in $\mathrm{Ca}^{2+}$-free $\mathrm{HBSS}$ at $28{ }^{\circ} \mathrm{C}$ for $40 \mathrm{~min}$. The protease digestion was terminated by incubation in M199 medium containing $10 \% \mathrm{FCS}$ at $28{ }^{\circ} \mathrm{C}$ for $5 \mathrm{~min}$, following by further digestions in $10 \mathrm{ng} / \mathrm{ml}$ DNaseI, $2 \mathrm{mM}$ EDTA, and $1 \mathrm{mM}$ EDTA at $28^{\circ} \mathrm{C}$ for $5 \mathrm{~min}$ respectively. Then, the loosened tissue was washed with $10 \mathrm{ng} / \mathrm{ml}$ DNaseI at $28{ }^{\circ} \mathrm{C}$ for $5 \mathrm{~min}$ and filtered through a $40 \mu \mathrm{m}$ nylon mesh. The dispersed pituitary cells were harvested by mild centrifugation $(200 \mathrm{~g}$ for $10 \mathrm{~min})$ and finally re-suspended in M199 medium. The viability of the cells was assessed by Trypan blue exclusion, and only preparations showing more than 95\% viability were used in subsequent experiments.

The grouper hypothalamus was dissected out and washed with M199 medium containing antibiotics. Then, it was 
1a 1 GTC AAT GGG CGT GAG GAG TCC CAG ACC CGG GGT GCC TTC AGC AGT AAG GGC CAG GCA CGG CCC CGT GAA TAA 72
16 1 GTC AAT GGG CGT GAG GAG TCC CAG ACC CGG GGT GCC TTC AGC AGT AAG GGC CAG GCA CGG CCC CGT GAA TAA 72 1a 73 CCG CGC AAC GAC AGC ATG CCC TCT TGG CCC AAT CTC TCG CTG TGC CTC TCC CAT AAC TGC AGC TGG GAG GAG 144

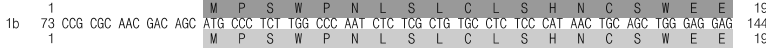
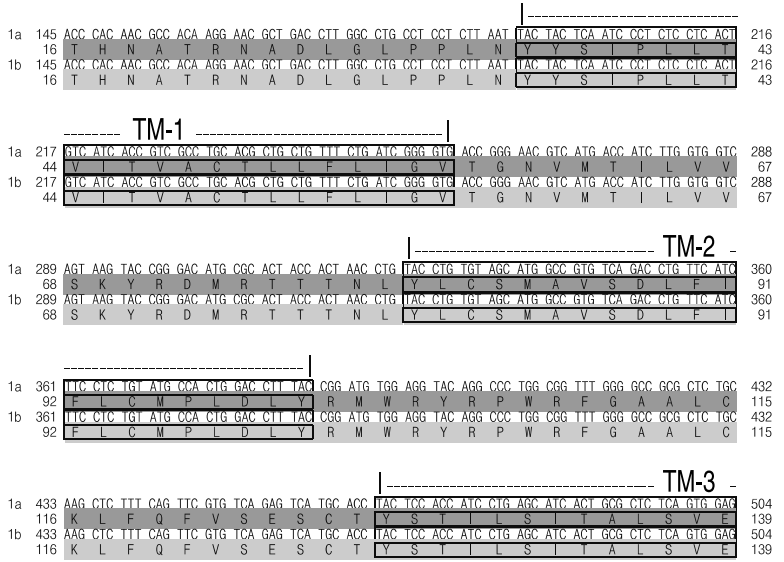

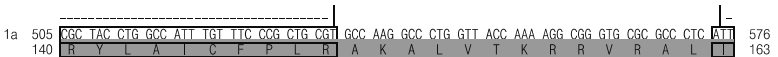

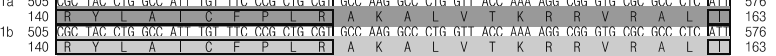
TM-4

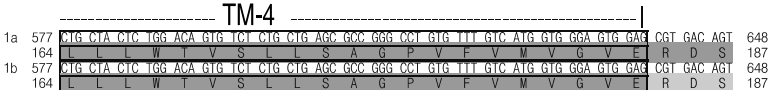

1a 649 ATG TGG CCA GAT TAC AGC TCT GGA ATG AAT GAG ACT GGC TTC TCC CCG GAG GAA ACG GAC ACC CGG GAG TGT 720

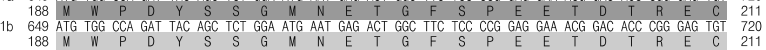

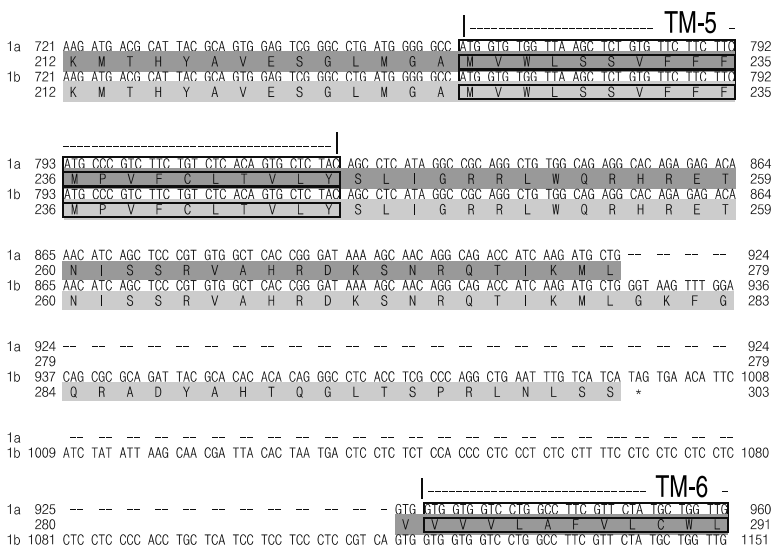

1 a

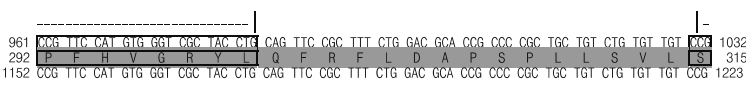

TM-7

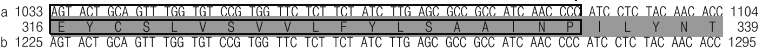

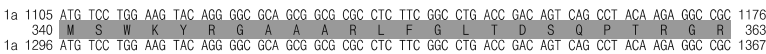

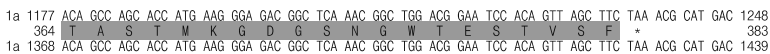

12 1249 TGT CAA AAA AGT GTG GAT ATG ATT TGA AAA ACG ATC AGT CCA AGA TGA TAA CAC TCA CCC AAA GCC ATT ATT 1320
16 1440 TGT CAA AAA AGT GTG GAT ATG ATT TGA AAA ACG ATC AGT CCA AGA TGA TAA CAC TCA CCC AAA GCC ATT ATT 1511 1a 1321 TCT GTC AGG GCC TAA GAG AAA AAC TGT TCT GCA CAT GTG AGT GCA GCA CTT GCC TIT ATT CAA CTGGGA CAA 1392
1a 1512 TCT GTC AGG GCC TAA GAG AAA AAC TGT TCT GCA CAT GTG AGT GCA GCA CTT GCC TTT ATT CAA CTG GGA CAA 1583 1a 1393 AAA GAA ACA GGA TGA GAA AAG TGC AAA CCA CAA AAA GCT GTA AGC CTC TAT CCA CTT TGT CAG CAC GCA TCA 1464
1a 1584 AAA GAA ACA GGA TGA GAA AAG TGC AAA CCA CAA AAA GCT GTA AGC CTC TAT CCA CTT TGT CAG CAC GCA TCA 1655 1a 1465 ATA GAA CTT CGA TTT TTG TCA AAC AAA AAA AAA AAA AAA AAA AAA AAA
1a 1156 ATA GAA CTT CGA TTT TTG TCA AAC AAA AAA AAA AAA AAA AAA AAA AAA

Figure 2 Comparisons of nucleotide and amino acid sequences between gpGHSR1a and gpGHSR1b. TM domains are boxed.

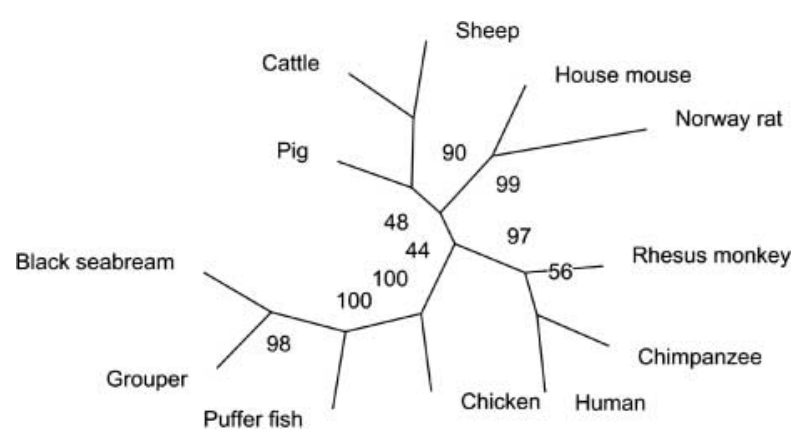

Figure 3 Phylogenetic tree of the gpGHSR1a amino acid sequence with other vertebrate species. The other amino acid sequences of GHSR1a were obtained from GenBank and phylogenetic tree was constructed using unrooted analysis with PHYLYP \& Tree View. Reliability of the tree was evaluated by the bootstrap method with 1000 replications. Black seabream, Acanthopagrus schlegelii (AY151040), Cattle, Bos taurus (XM_592014), Chicken, Gallus gallus (NM_204394), Chimpanzee, Pan troglodytes (XM_516878), House mouse, Mus musculus (NM_177330), Human, Homo sapiens (NM_198407), Pig, Sus scrofa (Q95254), Rhesus monkey, Macaca mulatta (XP_001084886), Norway rat, Rattus norvegicus (NM_032075), Pufferfish, Sphoeroides nephelus (AAC33472), and Sheep, Ovis aries (NM_001009760). diced into fragments $\left(<1 \mathrm{~mm}^{3}\right)$ with razor and washed thrice with M199 medium.

Dispersed pituitary cells $\left(2.5 \times 10^{5}\right.$ cells/well $)$ and hypothalamic fragments were cultured in 24-well plates in M199 medium (pH 7.2, with $100 \mathrm{U} / \mathrm{ml}$ penicillin, $100 \mathrm{U} / \mathrm{ml}$ streptomycin, and $10 \% \mathrm{FCS}$ ) at $28{ }^{\circ} \mathrm{C}$ with $5 \% \mathrm{CO}_{2}$ and saturated humidity. Samples were routinely incubated overnight to allow for recovery of membrane receptors after trypsin digestion. On the following day, the samples were washed with serum-free medium. The medium was removed again and replaced by medium containing stimulus, including seabream GH (Gropep, Thebarton, SA, Australia), rat ghrelin (Bachem AG, Switzerland), and rat des- $n$-octanoyl ghrelin (Bachem AG) in various concentrations at $28{ }^{\circ} \mathrm{C}$ for $45 \mathrm{~min}$.

After drug treatment, the medium was removed and the pituitary cells and hypothalamic fragments were collected and dissolved in Trizol reagent (Invitrogen). Total RNA extraction, first-strand cDNA synthesis, and expression levels analysis for two gpGHSR transcripts by real-time PCR were performed using the same protocols stated above. Data were normalized as percentage of each control groups and expressed as mean \pm S.D. $(n=3)$. Significant differences between each control and treatment groups were analyzed by ANOVA followed by 


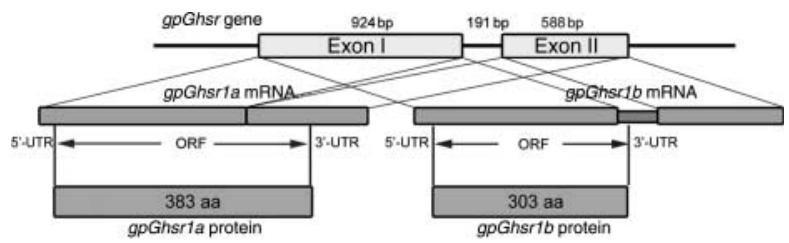

Figure 4 Diagram illustrating the intron/exon organization of the grouper Ghsr gene. Two exons are separated by a small intron. The deduced 383 aa gpGHSR1a protein is encoded by two exons, and the deduced 303 aa gpGHSR1b protein is encoded by exon I and part of the intron.

Fisher's least significance difference test (statistical analysis was done using SPSS 13.0, SPSS Inc., Chicago, IL, USA).

\section{Results}

\section{Cloning of grouper Ghsr1a and Ghsr1b cDNA}

In a partial cDNA cloning procedure, a $630 \mathrm{bp}$ fragment was amplified from grouper hypothalamus using a semi-nested RT-PCR approach. Subsequently, two fragments of 617 and $744 \mathrm{bp}$ were obtained in $3^{\prime}-$ and $5^{\prime}$-RACE respectively. During the further cloning of open reading frame (ORF), however, two bands of about 1200 and $1500 \mathrm{bp}$ were amplified, both of which were identified as transcripts of grouper GHSR (gpGHSR1a and gpGHSR 1b). The gp Ghsr1a cDNA was comprised of $1512 \mathrm{bp}$, including $87 \mathrm{bp}$ in the $5^{\prime}$-untranslated region (UTR), 276 bp in the $3^{\prime}$-UTR, and $1149 \mathrm{bp}$ in the ORF that encoded for a putative protein of $383 \mathrm{aa}$ with seven TM domains as indicated by hydrophobicity analysis. The gpGhsr1b cDNA was $1703 \mathrm{bp}$ in length, with a $5^{\prime}-\mathrm{UTR}$ of $87 \mathrm{bp}$, a $3^{\prime}$-UTR of $707 \mathrm{bp}$, and an ORF of $909 \mathrm{bp}$, encoding a putative protein of 303aa that lacked TM-6 and TM-7 found in gpGhsr1a (Fig. 2). The gpGhsr1b cDNA had an extra $192 \mathrm{bp}$, which contained a stop codon between the two fragments, the same as gp Ghsr 1a does. As a result, though $g p G h s r 1 b$ has a larger transcript size than $g p G h s r 1 a$, it actually encodes for a shorter truncated form of $g p G h s r 1 a$.

The aa sequence deduced from gp Ghsr1a cDNA shows high homology with other teleostean GHSR1a (black seabream: 93.0\%; pufferfish: $85 \cdot 6 \%$ ) and lower homology with those from avian and mammalian species (chicken: $64 \cdot 0 \%$, pig: $57 \cdot 1 \%$, sheep: $54 \cdot 4 \%$, cattle: $55 \cdot 7 \%$, house mouse: $55 \cdot 5 \%$, Norway rat: $54 \cdot 7 \%$, rhesus monkey: $56 \cdot 0 \%$, chimpanzee: $55 \cdot 7 \%$, and human: $55 \cdot 7 \%$ ). Phylogenetic tree analysis of the GHSR1a aa sequences in various vertebrate species shows that gpGHSR 1a clusters with high bootstrap in the lineage of other teleosts (black seabream and pufferfish), sharing the highest homology with black seabream, whereas the GHSR1a of avians (chicken) and mammals (pig, cattle, sheep, mouse, rat, monkey, chimpanzee, human) were grouped into two other distinct clusters (Fig. 3).

\section{Structure of grouper Ghsr gene}

In genomic PCR, a single product of $1340 \mathrm{bp}$ was amplified. The obtained Ghsr gene fragment had two exons (exon I of $924 \mathrm{bp}$ and exon II of $588 \mathrm{bp}$ ) separated by a small intron of $191 \mathrm{bp}$ (Fig. 4). Comparison of the cDNA sequences and the gene sequence revealed that $g p G h s r 1 a$ cDNA was composed of two exons: exon I contained the $5^{\prime}$-UTR up until Leu279 and exon II contained the left part of the G-protein-coupled receptor and the $3^{\prime}$-UTR. On the other hand, gpGhsr1b cDNA had completed the same sequence with the $g p G h s r$ gene. For gpGHSR1b transcript, the small intron was retained, thus giving rise to the longer transcript. However, the presence of a stop codon in the intron resulted in the truncated receptor with only five TM domains (Fig. 2).

\section{Tissue distribution of Ghsr1a and Ghsr1b $m R N A$ in grouper}

Assessment using RT-PCR followed by more sensitive Southern blot analysis in brain and peripheral tissues showed that $g p G h s r 1 a$ and $g p G h s r 1 b$ mRNA had different expression patterns. The expression of $g p$ Ghsr1a mRNA was predominantly observed in the seven brain regions and pituitary gland, and at much lower levels in heart, thymus, anterior intestine, middle intestine, posterior intestine, and liver, but there was no detectable expression in other tissues analyzed (Fig. 5). On the contrary, $g p G h s r 1 b$ mRNA was present in the all brain regions and peripheral tissues studied (Fig. 5).

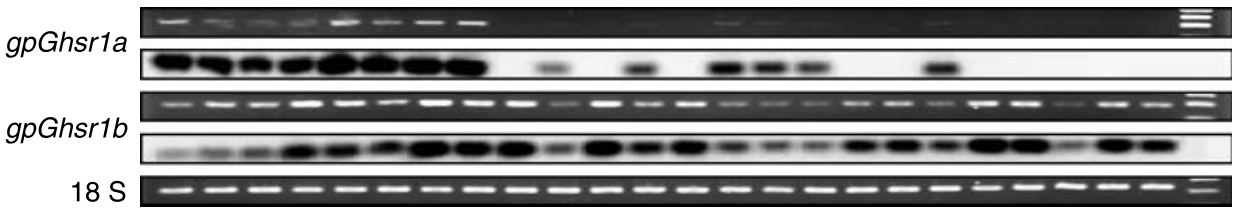

Figure 5 Tissue distribution of Ghsr1a and Ghsr1b mRNA in 2-years-old grouper. 1, olfactory bulbs; 2, telencephalon; 3, diencephalon; 4, cerebellum; 5, medulla; 6, spinal cord; 7, hypothalamus; 8, pituitary; 9, gill filament; 10, heart; 11 , spleen; 12 , liver; 13, stomach; 14, foreintestine; 15, midintestine; 16 , posteriorintestine; 17 , heart kidney; 18 , kidney; 19 , thymus; 20 , gonad; 21 , red muscle; 22 , white muscle; 23, skin; 24, fat; $M, 100$ bp marker. 


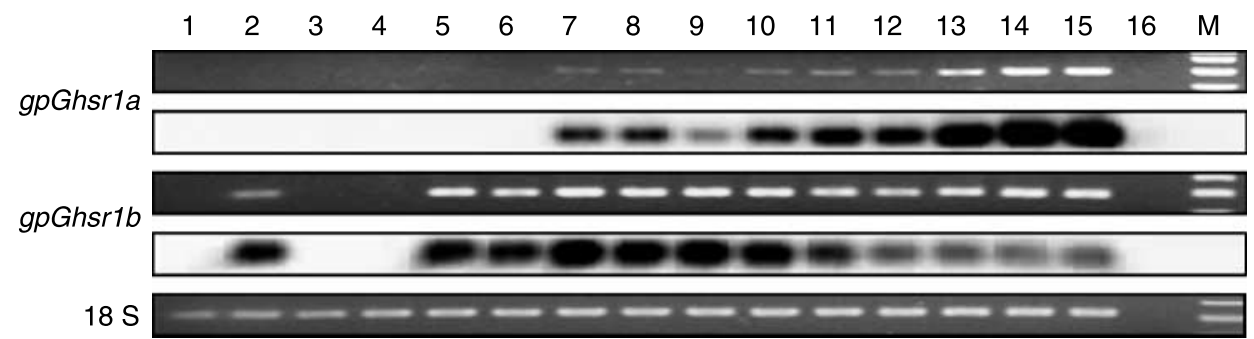

Figure 6 Expression of Ghsr1a and Ghsr1b mRNA in various embryonic and larval developmental stages in grouper. 1, unfertilized eggs; 2, fertilized eggs; 3, 16-cell stage; 4, morula stage; 5, blastula stage; 6, gastrula stage; 7 , neurula stage; 8 , crystal stage; 9 , hatch prophase; 10 , hatching; 11, 1 -dph; 12, 2-dph; 13, 3-dph; 14, 4-dph; 15, 5-dph; 16, negative control; M, 100 bp marker.

\section{Ontogeny of Ghsr1a and Ghsr1b mRNA in grouper}

Expression of gpGhsr1a and gpGhsr1b mRNA was also examined during embryonic and larval development, including unfertilized eggs, just fertilized eggs, 16-cell stage, morula stage, blastula stage, gastrula stage, neurula stage, crystal stage, hatch prophase, hatching, and larva at 1,2 , 3,4 , and $5 \mathrm{dph}$. The gp Ghsr1a mRNA was first detected from the neurula stage on with little change of expression even by $2 \mathrm{dph}$, then increased gradually from $3 \mathrm{dph}$ and reached a higher expression at $5 \mathrm{dph}$ (Fig. 6). In contrast, gpGhsr $1 \mathrm{~b}$ mRNA was found in fertilized but not in unfertilized eggs and, from blastula stage to $5 \mathrm{dph}$, it was expressed at a steady

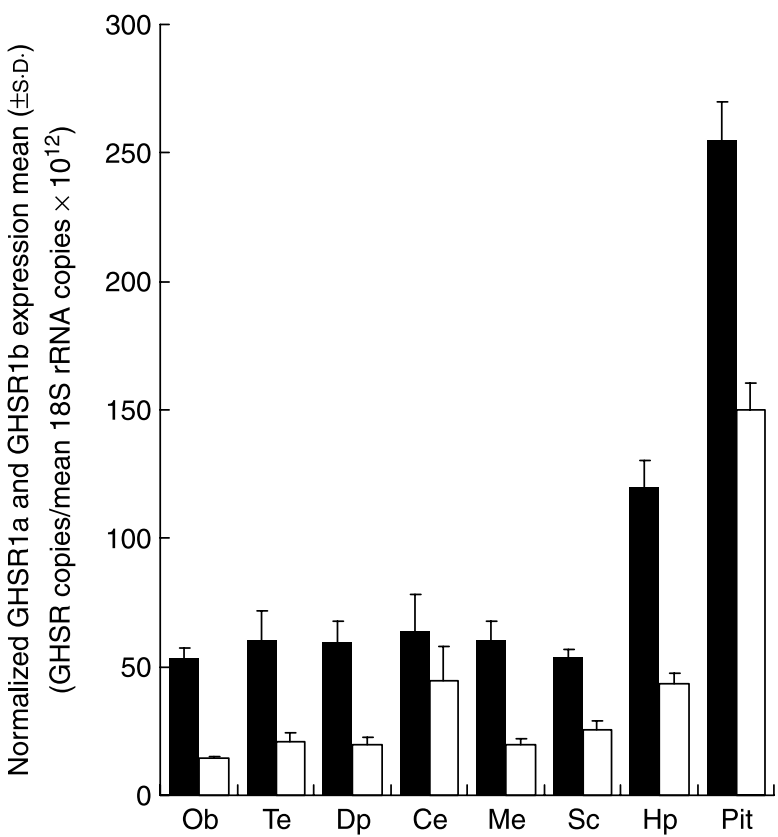

Figure 7 Real-time PCR quantification of GHSR1a and GHSR1b expression in brain and pituitary gland of 2-years-old grouper. Results are represented as means \pm s.D. $(n=3$ from three individual groupers). The gpGHSR copy numbers data were normalized by the geometric mean of copy data $\left(\times 10^{12}\right)$ from reference gene $18 \mathrm{~S}$ rRNA. Ob, olfactory bulbs; Te, telencephalon; $\mathrm{Dp}$, diencephalon; $\mathrm{Ce}$, cerebellum; Me, medulla; Sc, spinal cord; Hp, hypothalamus; Pit, pituitary. $\boldsymbol{\square}$, gpGHSR1a; $\square$, gpGHSR1b. level (Fig. 6). Southern blot analysis confirmed the authenticity of the RT-PCR result (Fig. 6).

\section{Quantification of Ghsr1a and Ghsr1b mRNA expression in grouper brain}

Since ghrelin exerts many of its known physiological functions on brain and in the pituitary gland, and since two transcripts of gpGHSR were highly expressed in these tissues, we used realtime PCR to quantify expression levels more accurately in these parts. Real-time PCR showed that both $g p G h s r 1 a$ and $g p$ Ghsr $1 b$ mRNAs were expressed in pituitary gland and all brain regions (Fig. 7), and confirmed the expression sites detected by RT-PCR. Both $g p G h s r 1 a$ and gpGhsr1b mRNA were most abundant in pituitary gland, for gpGHSR1a followed by hypothalamus, cerebellum, telencephalon, medulla, diencephalon, spinal cord, and olfactory bulbs, and for gpGHSR $1 \mathrm{~b}$ followed by cerebellum, hypothalamus, spinal cord, telencephalon, medulla, diencephalon, and olfactory bulbs. The expression levels of gpGHSR1a were higher than those of gpGHSR $1 b$ in all parts analyzed (Fig. 7).

\section{Localization of Ghsr $m R N A$ expression cells in grouper brain}

ISH of GHSR expressing cells on sagittal (Fig. 8A) and coronal (Fig. 8B) sections revealed a widespread distribution in several brain regions and the pituitary gland in grouper. To assess the relative contribution of the two transcripts of GHSR in grouper brain, adjacent brain sections were examined in parallel for hybridization with the probe against common region and the probe specifically against the gpGHSR1a transcript respectively. However, the expression patterns as detected by the two sets of probes were virtually identical both locally and quantitatively.

GHSR expressing cells in grouper brain showed diverse shapes and volumes in different regions. In olfactory bulbs and telencephalon, the GHSR expressing cells were small, round, and distributed orderly with a low density in the internal cell layer and a high density in the external cell layer (Fig. 8A2, B1 and B2). GHSR expressing cells were found in several regions of the diencephalon. They are of fusiform shape with obvious fibers in/connecting to the preoptic area and anterior 
hypothalamus (Fig. 8A3 and B4). Small and round cells were found in posterior hypothalamus similar to those in the telencephalon (Fig. 8A4, B4 and B5). In mesencephalon and cerebellum, GHSR expressing cells were small, fusiform in shape with bipolar structure and distributed annularly (Fig. 8A5 and A6). Besides, one sort of GHSR expressing cell of huge shape appeared in the medulla (Fig. 8A7 and B6). Otherwise, the positive signal was intense in pituitary tissue; however, the shape of GHSR expressing cells was not clear in this region (Fig. 8A8).

\section{Regulation of gp Ghsr $m R N A$ in pituitary and hypothalamus}

For gpGHSR $1 \mathrm{a}, 10^{-7} \mathrm{M}$ seabream $\mathrm{GH}$ reduced its mRNA expression only in primary cultured pituitary cells, and $10^{-5} \mathrm{M}$ rat ghrelin decreased its mRNA expression both in primary cultured pituitary cells and hypothalamic fragments, but other tests did not effectively alter mRNA levels (Fig. 9A). For gpGHR-R1b, $10^{-7} \mathrm{M}$ seabream GH downregulated mRNA expression in both primary cultured pituitary cells and hypothalamic fragments; $10^{-5} \mathrm{M}$ rat ghrelin decreased its expression only in cultured hypothalamic fragments (Fig. 9B). However, rat ghrelin at a concentration of $10^{-6} \mathrm{M}$ and $10^{-7} \mathrm{M}$ and rat des-acyl ghrelin in all concentrations tested did not significantly change the mRNA expression of both gpGHSR transcripts (Fig. 9A and B).

\section{Discussion}

Two full-length cDNAs, gpGHSR 1 a and gpGHSR $1 b$, for GHSR were cloned from grouper hypothalamus using RT-PCR and RACE methods. When compared with the full-length G-protein-coupled receptor gpGHSR 1a, which has seven TM domains, gpGHSR $1 \mathrm{~b}$ is a truncated receptor that lacks TM-6 and TM-7. The meaning of structural multiformity of GHSR for physiology in different species is still unclear. GHSR1a has been identified in all the species studied before, including humans, pig (Howard et al. 1996), rat (McKee et al. 1997), pufferfish (Palyha et al. 2000), chicken (Geelissen et al.

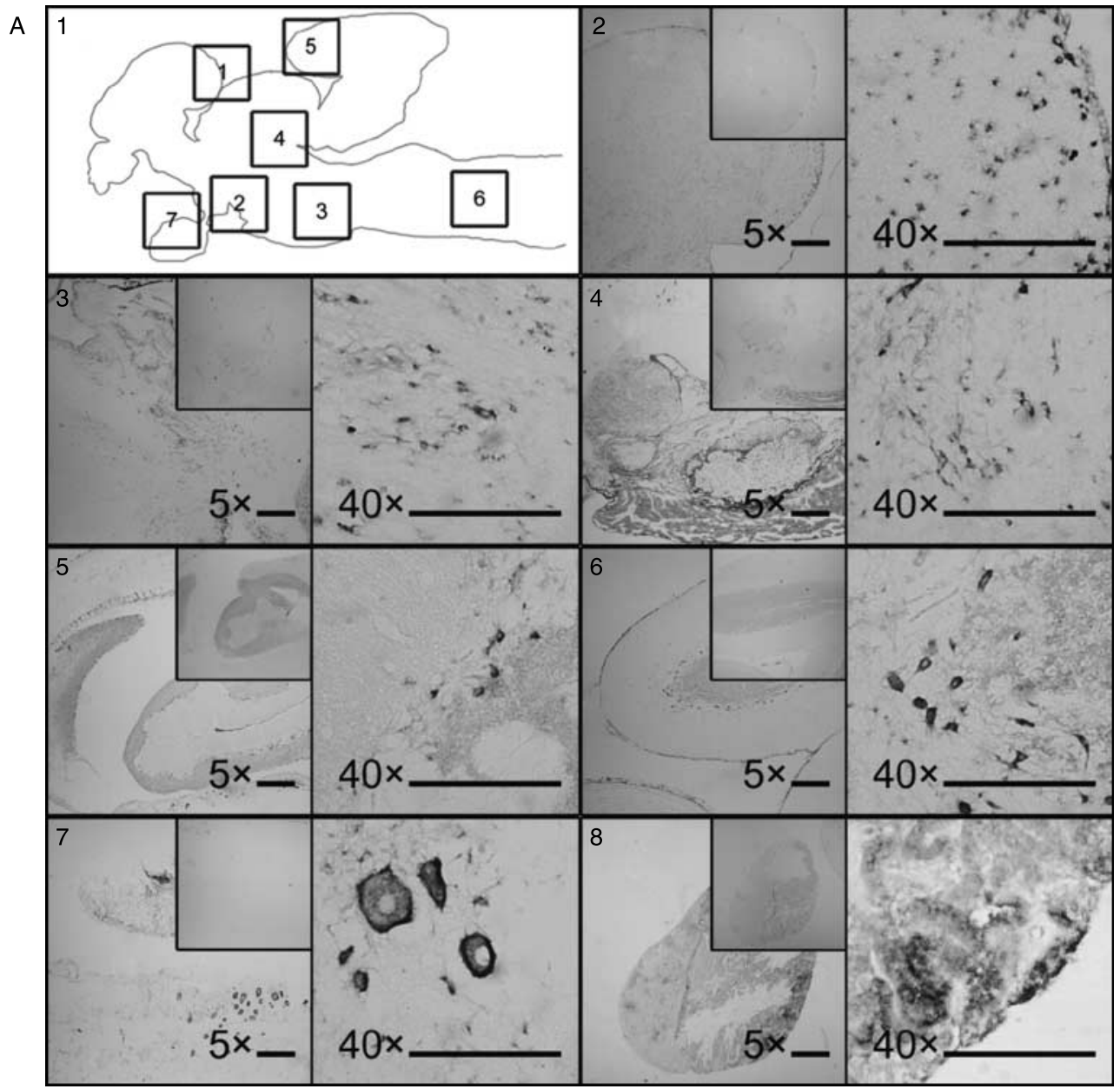

Figure 8 (continued) 


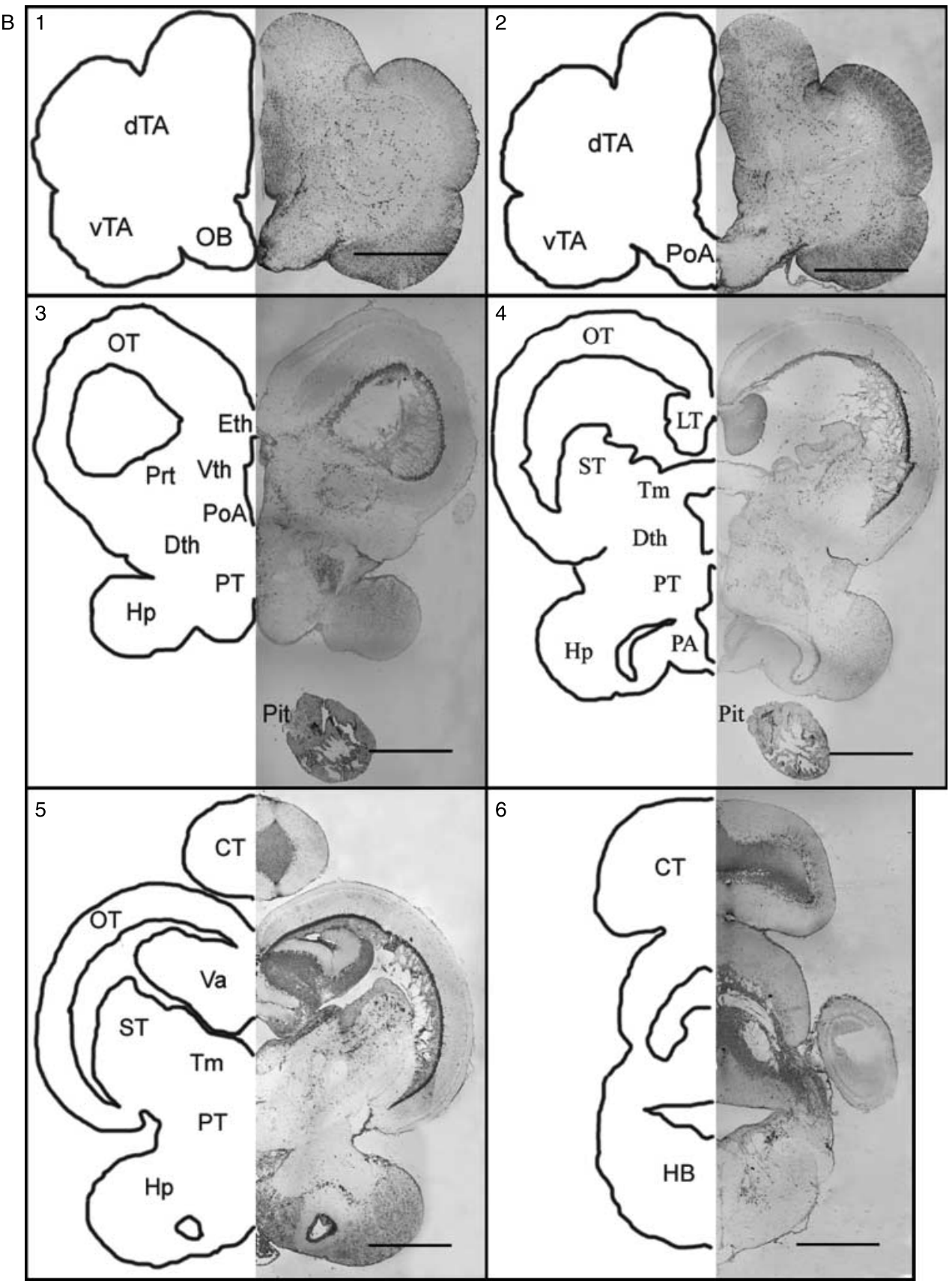

Figure 8 Sagittal and coronal sections schematic drawings and photos of the distribution of Ghsr mRNA expression cells in the brain of grouper. (A) sagittal sections. 1, schematic drawing; 2, telencephalon; 3, anterior hypothalamus; 4, posterior hypothalamus; 5 ,

diencephalons; 6, cerebellum; 7, medulla; 8, pituitary. Scale bars of $5 \times$ photos are $20 \mu \mathrm{m}$. Scale bars of $40 \times$ photos are $10 \mu \mathrm{m}$. No positive signal was found with the sense probe (inset). (B) coronal sections. 1, olfactory bulbs-telencephalon; 2, telencephalon; 3, telencephalondiencephalon-pituitary; 4, diencephalons-pituitary; 5, cerebellum-diencephalons-hypothalamus; 6 , cerebellum-medulla. Scale bars of $5 \times$ photos are $100 \mu \mathrm{m}$. Abbreviations: OB, olfactory bulbs; dTA, dorsal telencephalic area; vTA, ventral telencephalic area; PoA, preoptic area; Eth, epithalamus; Vth, ventral thalamus; Dth, dorsal thalamus; PT, posterior tuberculum; Hp, hypothalamus; PA, periventricular area; OT, optic tectum; Prt, pretectum; TM, tegmentum; ST, semicircular torus; LT, longitudinal torus; CT, cerebelli tectum; Va, valvula cerebelli; HB, hindbrain; Pit, pituitary. 
A

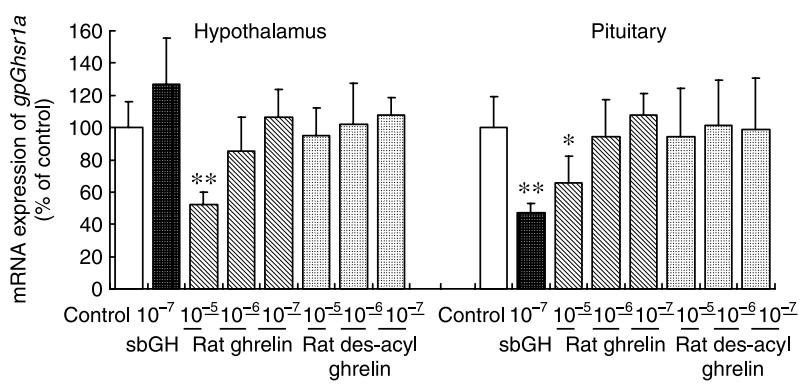

B

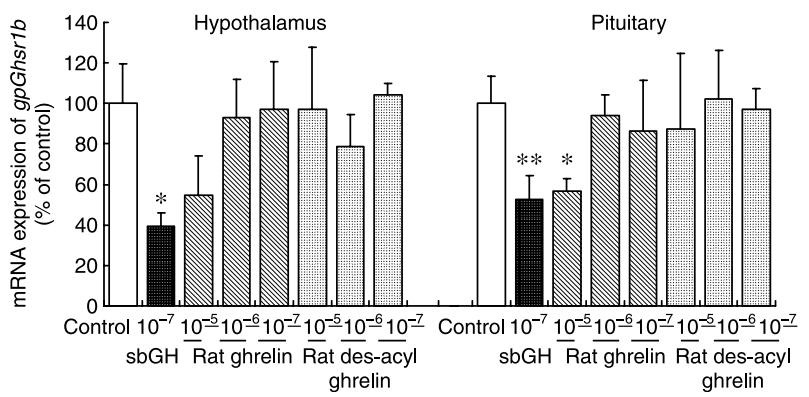

Figure 9 In vitro regulation of gpGHSR1a and gpGHSR1b in hypothalamus and pituitary tissue of grouper. The hormone administration is described in the figure. Results are represented as means \pm s.D. ( $n=3$ from three wells). Statistically significant differences among groups, obtained by ANOVA, were assessed by Fisher's LSD test and are indicated as follows: ${ }^{*} P<0 \cdot 05$ and $* * P<0 \cdot 01$.

2003), mouse (Sun et al. 2004), black seabream (Chan \& Cheng 2004), olive baboon (Luque et al. 2006), turkey (Richards et al. 2006), cattle (GenBank Acc XM_592014), rhesus monkey (GenBank Acc XP_001084886), and chimpanzee (GenBank Acc XM_516878). GHSR1b has only been reported so far in human, pig (Howard et al. 1996), and black seabream (Chan \& Cheng 2004). In Mozambique tilapia and rainbow trout, two transcripts of GHSR may also exist (unpublished observation by Kaiya, reviewed by Kaiya et al. 2008). In zebrafish, a novel GHSR paralogous sequence that has 74\% homology with the former reported GHSR1a has also been discovered in the genomic database and is named zebrafish GHSR2a (Kaiya et al. 2008). Moreover, another variant form of GHSR, designated GHSR1c or GHSR1aV, which lacks TM-6 when compared with GHSR1a due to a 48 bp deletion, has been detected in chicken and turkey (Geelissen et al. 2003, Tanaka et al. 2003, Richards et al. 2006). Our study provides new evidence for the existence of GHSR 1b in teleostean fishes. However, GHSR1c has not been found in grouper and other reported teleosts either, inferring that GHSR1c may be a specific form of GHSR that only exists in birds.

Phylogenetic analysis showed that gpGHSR 1a was evolutionary closer to other cloned GHSR1a sequences from teleostean species, but more distantly related to those from avian and mammalian species. Although the aa sequence of gpGHSR 1a shares only about 55\% identity with those of mammals, the TM domains of GHSR1a are conserved in various species. Moreover, the extracellular region between TM-2 and TM-3 of GHSR 1a is highly conserved, which shares $81 \cdot 5 \%$ identity between grouper and human, and this region is reported to be the active domain for ligand binding (Feighner et al. 1998, Palyha et al. 2000).

The structure of the grouper Ghsr gene was very similar to that of black seabream (Chan \& Cheng 2004), whose two exons are separated by a small intron; in human and rat genes (McKee et al. 1997, Petersenn et al. 2001), the intron may comprise up to $2 \mathrm{~kb}$. We also predicted the structures of Ghsr genes from other vertebrate species based on genomic databases using the Blast search method. In cow, chicken and some teleosts including zebrafish, fugu, Takifugu rubripes, and pufferfish, Tetraodon nigroviridis, Ghsr genes have a big hypothetical intron. However, in other teleosts such as medaka, Oryzias latipes, and stickleback, Gasterosteus aculeatus, the hypothetic intron of GHSR is less than only $200 \mathrm{bp}$. Therefore, we speculate that the small intron is characteristic of the Ghsr gene in teleostean fishes.

Both Ghsr1a and Ghsr1b mRNAs were highly expressed in the brain and pituitary gland of grouper. The appearance of gpGhsr mRNA in brain and pituitary is consistent with the main acting sites of ghrelin. Besides stimulating GH secretion (Kojima et al. 1999, Riley et al. 2002, Kaiya et al. 2003a,b, Ran et al. 2004, Shepherd et al. 2007), ghrelin has also been reported to be involved in other physiological functions controlled by central nervous system, including energy expenditure (Tschop et al. 2000), feeding behavior (Nakazato et al. 2001, Unniappan et al. 2002, 2004, Matsuda et al. 2006a, Jönsson et al. 2007, Miura et al. 2007, Shepherd et al. 2007), and sleep quality (Copinschi et al. 1997). The grouper active receptor form of ghrelin, gpGHSR1a, shows a similar expression pattern as that seen in black seabream (Chan \& Cheng 2004). In teleosts, the expression levels of GHSR 1a in brain regions can achieve $10-60 \%$ of that in pituitary gland. However, in human and rat, Ghsr1a mRNA is only predominantly expressed in pituitary gland and hypothalamus (McKee et al. 1997, Muccioli et al. 1998), but could not be detected in other brain regions by RNase protection assay most likely due to its low abundance and the low sensitivity of this procedure (McKee et al. 1997).

For ISH analysis, GHSR expressing cells in the brain and pituitary of grouper are widespread, in accordance with the result of real-time PCR. The GHSR positive cells were distributed widely and randomly in olfactory bulbs, telencephalon, diencephalon, cerebellum, medulla, spinal cord, hypothalamus, and pituitary gland. In some nuclei, the densities of GHSR-positive cells were higher than other regions. Previous research on mammalian species has shown that GHSR expressing cells can also be detected in several hypothalamic nuclei and other discrete regions (McKee et al. 1997, Zigman et al. 2006). Yet their distribution is confined in these sites and exhibits a clear pattern of zonal distribution (McKee et al. 1997), different from the situation of our study in teleosts. In the arcuate 
nucleus of rat, GHSR expressing cells have been reported to co-localize with neuropeptide Y $(94 \% \pm 1 \%)$, somatostatin $(30 \pm 6 \%)$, and GH-releasing hormone (20-25\%; Willesen et al. 1999), and all these neuroendocrine factors are distributed more widely in teleostean brains than in their mammalian counterparts (Traverso et al. 2003, Chen et al. 2005, Ye et al. 2005, Lee et al. 2007). Hence, in the teleostean brain, these cells may play a more important endocrine role than in mammalian brains.

In peripheral tissues, the $g p G h s r 1 a$ mRNA were detected in heart, thymus, along the intestine, and in liver, which corresponds to a ghrelin involvement in cardiovascular action (Tivesten et al. 2000), immune regulation (Koo et al. 2001, Dixit et al. 2004), and gastric acid secretion (Sibilia et al. 2002). The peripheral expression of GHSR 1a in humans is limited to the thyroid, pancreas, spleen, myocardium, and adrenal besides brain and pituitary gland (Gnanapavan et al. 2002). However, in chicken, Ghsr1a mRNA has been found in almost all peripheral tissues (Geelissen et al. 2003, Tanaka et al. 2003, Richards et al. 2006), suggesting that the expression patterns of Ghsr1a mRNA are distinct among species.

On the contrary, the $g p G h s r 1 b$ mRNA was observed in all peripheral tissues at similar expression levels. The tissue expression of gpGHSR $1 \mathrm{~b}$ is more widespread than previously reported for black seabream (Chan \& Cheng 2004) but similar with the scenario in humans (Gnanapavan et al. 2002). GHSR $1 b$ is an inactive form of ghrelin receptor and reported to localize in the nucleus of the cell, while GHSR $1 \mathrm{a}$ is on the plasma membrane (Smith et al. 2005). However, when GHSR 1b is co-expressed with GHSR1a in a cell line, the signal transduction capacity of GHSR 1a is attenuated (Chan \& Cheng 2004) and this suggests a cross-talk function of the splice variant. Since the mRNA tissue distribution of Ghsr $1 b$ is much wider than Ghsr1a in grouper, we speculate that GHSR1b may mediate some unknown functions independent of ghrelin/GHSR1a system.

During embryonic and larval development, gpGhsr1a mRNA was expressed from the neurula stage on, coinciding with the development of the nervous system and prior to the appearance of its ligand, ghrelin, which is expressed from hatching in Atlantic halibut (Manning et al. 2008). The expression of $g p G h s r 1 b$ mRNA can be detected as of the blastula stage, even earlier than $g p G h s r 1 a$. A role in embryonic development, independent of ghrelin/GHSR 1a system, may be more relevant for gpGHSR 1b. Besides, the expression of Ghsr mRNA has also been reported in chicken embryonic development, but the isoform of GHSR was not addressed in this report (Gahr et al. 2004).

In our in vitro study, seabream $\mathrm{GH}$ potently reduced the expression of two gp Ghsr mRNA in pituitary and only gp Ghsr $1 b$ mRNA in hypothalamus. The expression of Ghsr mRNA in pituitary gland and hypothalamus may decrease by $\mathrm{GH}$ in vitro (Geelissen et al. 2003) and in vivo (Bennett et al. 1997, Horikawa et al. 2000), and GH is reported to negatively feedback on many GH-releasing factors and their receptors in teleosts (Wong et al. 2006). Our study provides new evidence of $\mathrm{GH}$ feedback regulation of GHSR in a teleost, and suggests that a more complicated regulation between ghrelin and $\mathrm{GH}$ may exist.

Rat ghrelin at $10^{-5} \mathrm{M}$ downregulated the expression of two gpGHSR transcripts in pituitary gland and only the gpGHSR 1a in hypothalamus. However, rat des-acyl ghrelin does not change the expression of both transcripts at all concentrations we used. Ghrelin is not a well-conserved peptide among vertebrate species (Unniappan \& Peter 2005), but its N-terminal biological active core (GSSF with an acyl modification at the third residue) shows complete conservation among all species (Kaiya et al. 2008). The active core can functionally activate GHSR 1a as efficiently as the full-length ghrelin and the entire sequence of ghrelin is not necessary for its activity (Bednarek et al. 2000). Otherwise, rat ghrelin has been reported to effectively activate seabream GHSR 1a in vitro (Chan \& Cheng 2004), and eel ghrelin can also activate rat GHSR 1a in vitro and in vivo (Kaiya et al. 2003a). Therefore, rat ghrelin may influence the expression of gpGHSR via action on the gpGHSR1a. In chicken, both Ghsr1a and Ghsr1c mRNA can be downregulated by chicken ghrelin in pituitary cells (Geelissen et al. 2003), in agreement with the situation in our study. Our study provides evidence that ghrelin can also reduce the expression of both GHSR transcripts in hypothalamus. As des-acyl ghrelin did not change the expression of both GHSR transcripts in our study, we conclude that acylation is required for the ligand of the GHSR in this fish.

In summary, we have described and characterized two transcripts of Ghsr cDNA in grouper, providing new evidence for a splice variant in teleosts. The short intron may be one of the characteristics of Ghsr gene in teleostean fishes. Tissue distribution reflected that gpGHSR1a mediating some physiological functions of ghrelin; the function of the gpGHSR 1b awaits further study but seems independent of the ghrelin/GHSR system. The expression of GHSR in grouper brain is both quantitatively and in distribution pattern different from that in mammals, as GHSR expressing cells are distributed more widely and randomly in fish brain than in mammalian brain. The Ghsr mRNA expression during fish embryonic and larval development was also examined, and it was shown that the appearance and expression profile of the two gpGHSR transcripts is different during development. In addition, in vitro experiments showed that the expression of both $g p G h s r 1 a$ and gpGhsr $1 b$ mRNA are downregulated by rat ghrelin and seabream GH, strong evidence for a role of feedback regulation by these substances in teleosts.

\section{Declaration of interest}

The authors declare that there is no conflict of interest that could be perceived as prejudicing the impartiality of the research reported.

\section{Funding}

This work was supported by the National Natural Science Foundation of China (No. 30671626), National '863' Development Project (2007AA091404), the 
National Basic Research Program (973 program, No. 2004CB117402), and the Guangdong Provincial Science and technology Program (No. 2006B36501006) to Dr Wensheng Li.

\section{Acknowledgements}

Thanks to Dr Rong Chen for her assistance at embryo and larva collection.

\section{References}

Bednarek MA, Feighner SD, Pong SS, McKee KK, Hreniuk DL, Silva MV, Warren VA, Howard AD, van der Ploeg LH \& Heck JV 2000 Structurefunction studies on the new growth hormone-releasing peptide, ghrelin: minimal sequence of ghrelin necessary for activation of growth hormone secretagogue receptor 1a. Journal of Medicinal Chemistry 43 4370-4376.

Bennett PA, Thomas GB, Howard AD, Feighner SD, van der Ploeg LH, Smith RG \& Robinson IC 1997 Hypothalamic growth hormone secretagogue -receptor (GHS-R) expression is regulated by growth hormone in the rat. Endocrinology 138 4552-4557.

Bowers CY, Momany F, Reynolds GA, Chang D, Hong A \& Chang K 1980 Structure-activity relationships of a synthetic pentapeptide that specifically releases growth hormone in vitro. Endocrinology 106 663-667.

Bowers CY, Momany FA, Reynolds GA \& Hong A 1984 On the in vitro and in vivo activity of a new synthetic hexapeptide that acts on the pituitary to specifically release growth hormone. Endocrinology 114 1537-1545.

Chan CB \& Cheng CH 2004 Identification and functional characterization of two alternatively spliced growth hormone secretagogue receptor transcripts from the pituitary of black seabream Acanthopagrus schlegeli. Molecular and Cellular Endocrinology 214 81-95.

Chan CB, Leung PK, Wise H \& Cheng CH 2004 Signal transduction mechanism of the seabream growth hormone secretagogue receptor. FEBS Letters 577 147-153.

Chen R, Li W \& Lin H 2005 cDNA cloning and mRNA expression of neuropeptide $\mathrm{Y}$ in orange spotted grouper, Epinephelus coioides. Comparative Biochemistry and Physiology. Part B, Biochemistry and Molecular Biology 142 79-89.

Copinschi G, Leproult R, van Onderbergen A, Caufriez A, Cole KY, Schilling LM, Mendel CM, De Lepeleire I, Bolognese JA \& van Cauter E 1997 Prolonged oral treatment with MK-677, a novel growth hormone secretagogue, improves sleep quality in man. Neuroendocrinology $\mathbf{6 6}$ 278-286.

Dixit VD, Schaffer EM, Pyle RS, Collins GD, Sakthivel SK, Palaniappan R, Lillard JW \& Taub DD 2004 Ghrelin inhibits leptin- and activationinduced proinflammatory cytokine expression by human monocytes and $\mathrm{T}$ cells. Journal of Clinical Investigation 114 57-66.

Feighner SD, Howard AD, Prendergast K, Palyha OC, Hreniuk DL, Nargund R, Underwood D, Tata JR, Dean DC, Tan CP et al. 1998 Structural requirements for the activation of the human growth hormone secretagogue receptor by peptide and nonpeptide secretagogues. Molecular Endocrinology 12 137-145.

Fox BK, Riley LG, Dorough C, Kaiya H, Hirano T \& Grau EG 2007 Effects of homologous ghrelins on the growth hormone/insulin-like growth factor-I axis in the tilapia, Oreochromis mossambicus. Zoological Science $\mathbf{2 4}$ 391-400.

Gahr SA, Kocamis H, Richter JJ \& Killefer J 2004 The effects of in ovo rhIGF-I administration on expression of the growth hormone secretagogue receptor (GHSR) during chicken embryonic development. Growth, Development, and Aging 68 3-10.

Geelissen SM, Beck IM, Darras VM, Kühn ER \& van der Geyten S 2003 Distribution and regulation of chicken growth hormone secretagogue receptor isoforms. General and Comparative Endocrinology 134 167-174.

Gnanapavan S, Kola B, Bustin SA, Morris DG, McGee P, Fairclough P, Bhattacharya S, Carpenter R, Grossman AB \& Korbonits M 2002 The tissue distribution of the mRNA of ghrelin and subtypes of its receptor, GHS-R, in humans. Journal of Clinical Endocrinology and Metabolism 87 2988-2991.
Horikawa R, Tachibana T, Katsumata N, Ishikawa H \& Tanaka T 2000 Regulation of pituitary growth hormone-secretagogue and growth hormone-releasing hormone receptor RNA expression in young Dwarf rats. Endocrine Journal 47 S53-56.

Howard AD, Feighner SD, Cully DF, Arena JP, Liberator PA, Rosenblum CI, Hamelin M, Hreniuk DL, Palyha OC, Anderson J et al. 1996 A receptor in pituitary and hypothalamus that functions in growth hormone release. Science 273 974-977.

Jönsson E, Forsman A, Einarsdottir IE, Kaiya H, Ruohonen K \& Björnsson BT 2007 Plasma ghrelin levels in rainbow trout in response to fasting, feeding and food composition, and effects of ghrelin on voluntary food intake. Comparative Biochemistry and Physiology. Part A, Molecular and Integrative Physiology 47 1116-1124.

Kaiya H, Kojima M, Hosoda H, Riley LG, Hirano T, Grau EG \& Kangawa K 2003a Amidated fish ghrelin: purification, cDNA cloning in the Japanese eel and its biological activity. Journal of Endocrinology 176 415-423.

Kaiya H, Kojima M, Hosoda H, Moriyama S, Takahashi A, Kawauchi H \& Kangawa K 2003b Peptide purification, cDNA and genomic DNA cloning, and functional characterization of ghrelin in rainbow trout. Endocrinology 144 5215-5226.

Kaiya H, Kojima M, Hosoda H, Riley LG, Hirano T, Grau EG \& Kangawa K $2003 c$ Identification of tilapia ghrelin and its effects on growth hormone and prolactin release in the tilapia, Oreochromis mossambicus. Comparative Biochemistry and Physiology. Part B, Biochemistry and Molecular Biology 135 421-429.

Kaiya H, Small BC, Bilodeau AL, Shepherd BS, Kojima M, Hosoda H \& Kangawa K 2005 Purification, cDNA cloning, and characterization of ghrelin in channel catfish, Ictalurus punctatus. General and Comparative Endocrinology 143 201-210.

Kaiya H, Miyazato M, Kangawa K, Peter RE \& Unniappan S 2008 Ghrelin: a multifunctional hormone in non-mammalian vertebrates. Comparative Biochemistry and Physiology. Part A, Molecular and Integrative Physiology 149 109-128.

Kojima M \& Kangawa K 2005 Ghrelin: structure and function. Physiological Reviews 85 495-522.

Kojima M, Hosoda H, Date Y, Nakazato M, Matsuo H \& Kangawa K 1999 Ghrelin is a growth-hormone-releasing acylated peptide from stomach. Nature 402 656-660.

Koo GC, Huang C, Camacho R, Trainor C, Blake JT, Sirotina-Meisher A, Schleim KD, Wu TJ, Cheng K, Nargund R et al. 2001 Immune enhancing effect of a growth hormone secretagogue. Journal of Immunology 166 4195-4201.

Kozaka T \& Ando M 2003 Cholinergic innervation to the upper esophageal sphincter muscle in the eel, with special reference to drinking behavior. Journal of Comparative Physiology, B 173 135-140.

Lee LT, Siu FK, Tam JK, Lau IT, Wong AO, Lin MC, Vaudry H \& Chow BK 2007 Discovery of growth hormone-releasing hormones and receptors in nonmammalian vertebrates. PNAS 104 2133-2138.

van der Lely AJ, Tschöp M, Heiman ML \& Ghigo E 2004 Biological, physiological, pathophysiological, and pharmacological aspects of ghrelin. Endocrine Reviews 25 426-457.

Li WS, Chen D, Wong AO \& Lin HR 2005 Molecular cloning, tissue distribution, and ontogeny of mRNA expression of growth hormone in orange-spotted grouper (Epinephelus coioides). General and Comparative Endocrinology 144 78-89.

Luque RM, Gahete MD, Valentine RJ \& Kineman RD 2006 Examination of the direct effects of metabolic factors on somatotrope function in a non-human primate model, Papio Anubis. Journal of Molecular Endocrinology 37 25-38.

Manning AJ, Murray HM, Gallant JW, Matsuoka MP, Radford E \& Douglas SE 2008 Ontogenetic and tissue-specific expression of preproghrelin in the Atlantic halibut, Hippoglossus hippoglossus L. Journal of Endocrinology 196 181-192.

Matsuda K, Miura T, Kaiya H, Maruyama K, Shimakura S, Uchiyama M, Kangawa K \& Shioda S 2006a Regulation of food intake by acyl and des-acyl ghrelins in the goldfish. Peptides 27 2321-2325.

Matsuda K, Miura T, Kaiya H, Maruyama K, Uchiyama M, Kangawa K \& Shioda S $2006 b$ Stimulatory effect of $n$-octanoylated ghrelin on locomotor activity in the goldfish, Carassius auratus. Peptides 27 1335-1340. 
McKee KK, Palyha OC, Feighner SD, Hreniuk DL, Tan CP, Phillips MS, Smith RG, van der Ploeg LH \& Howard AD 1997 Molecular analysis of rat pituitary and hypothalamic growth hormone secretagogue receptors. Molecular Endocrinology 11 415-423.

Miura T, Maruyama K, Shimakura S, Kaiya H, Uchiyama M, Kangawa K, Shioda S \& Matsuda K 2007 Regulation of food intake in the goldfish by interaction between ghrelin and orexin. Peptides 28 1207-1213.

Muccioli C, Ghe C, Ghigo MC, Papotti M, Arvat E, Boghen MF, Nilsson MH, Deghenghi R, Ong H \& Ghigo E 1998 Specific receptors for synthetic GH secretagogues in the human brain and pituitary gland. Journal of Endocrinology 157 99-106.

Muller EE, Locatelli V \& Cocchi D 1999 Neuroendocrine control of growth hormone secretion. Physiological Reviews 79 511-607.

Mustonen AM, Nieminen P \& Hyvärinen H 2002 Leptin, ghrelin, and energy metabolism of the spawning burbot (Lota lota, L.). Journal of Experimental Zoology 293 119-126.

Nakazato M, Murakami N, Date Y, Kojima M, Matsuo H, Kangawa K \& Matsukura S 2001 A role for ghrelin in the central regulation of feeding. Nature 409 194-198.

Olsson C, Holbrook JD, Bompadre G, Jönsson E, Hoyle CH, Sanger GJ, Holmgren S \& Andrews PL 2008 Identification of genes for the ghrelin and motilin receptors and a novel related gene in fish, and stimulation of intestinal motility in zebrafish (Danio rerio) by ghrelin and motilin. General and Comparative Endocrinology 155 217-226.

Palyha OC, Feighner SD, Tan CP, McKee KK, Hreniuk DL, Gao YD, Schleim KD, Yang L, Morriello GJ, Nargund R et al. 2000 Ligand activation domain of human orphan growth hormone $(\mathrm{GH})$ secretagogue receptor (GHS-R) conserved from pufferfish to humans. Molecular Endocrinology 14 160-169.

Parhar IS, Sato H \& Sakuma Y 2003 Ghrelin gene in cichlid fish is modulated by sex and development. Biochemical and Biophysical Research Communications 305 169-175.

Peng C \& Peter RE 1997 Neuroendocrine regulation of growth hormone secretion and growth in fish. Zoological Studies 36 79-89.

Petersenn S, Rasch AC, Penshorn M, Beil FU \& Schulte HM 2001 Genomic structure and transcriptional regulation of the human growth hormone secretagogue receptor. Endocrinology 142 2649-2659.

Ran XQ, Li WS \& Lin HR 2004 Stimulatory effects of gonadotropinreleasing hormone and dopamine on growth hormone release and growth hormone mRNA expression in Epinephelus coioides. Sheng Li Xue Bao 56 644-650.

Richards MP, Poch SM \& McMurtry JP 2006 Characterization of turkey and chicken ghrelin genes, and regulation of ghrelin and ghrelin receptor mRNA levels in broiler chickens. General and Comparative Endocrinology 145 298-310.

Riley LG, Hirano T \& Grau EG 2002 Rat ghrelin stimulates growth hormone and prolactin release in the tilapia, Oreochromis mossambicus. Zoological Science $19797-800$

Riley LG, Fox BK, Kaiya H, Hirano T \& Grau EG 2005 Long-term treatment of ghrelin stimulates feeding, fat deposition, and alters the GH/IGF-I axis in the tilapia, Oreochromis mossambicus. General and Comparative Endocrinology 142 234-240.

Shepherd BS, Johnson JK, Silverstein JT, Parhar IS, Vijayan MM, McGuire A \& Weber GM 2007 Endocrine and orexigenic actions of growth hormone secretagogues in rainbow trout (Oncorhynchus mykiss). Comparative Biochemistry and Physiology. Part A, Molecular and Integrative Physiology 146 390-399.

Sibilia V, Pagani F, Guidobono F, Locatelli V, Torsello A, Deghenghi R \& Netti C 2002 Evidence for a central inhibitory role of growth hormone secretagogues and ghrelin on gastric acid secretion in conscious rats. Neuroendocrinology 75 92-97.

Smith RG, van der Ploeg LH, Howard AD, Feighner SD, Cheng K, Hickey GJ, Wyvratt MJ, Fisher MH, Nargund RP \& Patchett AA 1997 Peptidomimetic regulation of growth hormone secretion. Endocrine Reviews 18 621-645.

Smith R G, Jiang H \& Sun Y 2005 Developments in ghrelin biology and potential clinical relevance. Trends in Endocrinology and Metabolism 16 436-442.

Sun Y, Wang P, Zheng H \& Smith RG 2004 Ghrelin stimulation of growth hormone release and appetite is mediated through the growth hormone secretagogue receptor. PNAS 101 4679-4684.
Tanaka M, Miyazaki T, Yamamoto I, Nakai N, Ohta Y, Tsushima N, Wakita M \& Shimada K 2003 Molecular characterization of chicken growth hormone secretagogue receptor gene. General and Comparative Endocrinology 134 198-202.

Terova G, Rimoldi S, Bernardini G, Gornati R \& Saroglia M 2008 Sea bass ghrelin: molecular cloning and mRNA quantification during fasting and refeeding. General and Comparative Endocrinology 155 341-351.

Tivesten A, Bollano E, Caidahl K, Kujacic V, Sun XY, Hedner T, Hjalmarson A, Bengtsson BA \& Isgaard J 2000 The growth hormone secretagogue hexarelin improves cardiac function in rats after experimental myocardial infraction. Endocrinology 141 60-66.

Traverso JM, Ravaglia MA, Vissio PG, Maggese MC \& Paz DA 2003 Localization of neuropeptide Y-like immunoreactive structures in the brain of the pejerrey, Odontesthes bonariensis (Teleostei, Atheriniformes). Anatomia, Histologia, Embryologia 32 29-35.

Tschop M, Smiley DL \& Heiman ML 2000 Ghrelin induces adiposity in rodents. Nature 407 908-913.

Unniappan S \& Peter RE 2005 Structure, distribution and physiological functions of ghrelin in fish. Comparative Biochemistry and Physiology. Part A, Molecular and Integrative Physiology 140 396-408.

Unniappan S, Lin X, Cervini L, Rivier J, Kaiya H, Kangawa K \& Peter RE 2002 Goldfish ghrelin: molecular characterization of the complementary deoxyribonucleic acid, partial gene structure, and evidence for its stimulatory role in food intake. Endocrinology 143 4143-4146.

Unniappan S, Canosa LF \& Peter RE 2004 Orexigenic actions of ghrelin in goldfish: feeding-induced changes in brain and gut mRNA expression and serum levels, and responses to central and peripheral injections. Neuroendocrinology 79 100-108.

Willesen MG, Kristensen P \& Rømer J 1999 Co-localization of growth hormone secretagogue receptor and NPY mRNA in the arcuate nucleus of the rat. Neuroendocrinology 70 306-316.

Wong AO, Ng S, Lee EK, Leung RC \& Ho WK 1998 Somatostatin inhibits (d-Arg6, Pro9-NEt) salmon gonadotropin-releasing hormone- and dopamine D1-stimulated growth hormone release from perifused pituitary cells of chinese grass carp, Ctenopharyngodon idellus. General and Comparative Endocrinology 110 29-45.

Wong AO, Zhou H, Jiang Y \& Ko WK 2006 Feedback regulation of growth hormone synthesis and secretion in fish and the emerging concept of intrapituitary feedback loop. Comparative Biochemistry and Physiology. Part A, Molecular \& Integrative Physiology 144 284-305.

Yada T, Kaiya H, Mutoh K, Azuma T, Hyodo S \& Kangawa K 2006 Ghrelin stimulates phagocytosis and superoxide production in fish leukocytes. Journal of Endocrinology 189 57-65.

Yang J, Brown MS, Liang G, Grishin NV \& Goldstein JL 2008 Identification of the acyltransferase that octanoylates ghrelin, an appetite-stimulating peptide hormone. Cell 132 387-396.

Ye X, Li W \& Lin H 2005 Polygenic expression of somatostatin in orangespotted grouper (Epinephelus coioides): molecular cloning and distribution of the mRNAs encoding three somatostatin precursors. Molecular and Cellular Endocrinology 241 62-72.

Yeung CM, Chan CB \& Cheng CH 2004 Isolation and characterization of the $5^{\prime}$-flanking region of the growth hormone secretagogue receptor gene from black seabream Acanthopagrus schlegeli. Molecular and Cellular Endocrinology 223 5-15.

Yeung CM, Chan CB, Woo NY \& Cheng CH 2006 Seabream ghrelin: cDNA cloning, genomic organization and promoter studies. Journal of Endocrinology $189365-379$.

Zigman JM, Jones JE, Lee CE, Saper CB \& Elmquist JK 2006 Expression of ghrelin receptor mRNA in the rat and the mouse brain. Journal of Comparative Neurology 494 528-548.

Received in final form 3 August 2008

Accepted 22 August 2008

Made available online as an Accepted Preprint 26 August 2008 